Preprint version of a manuscript published as : Dupuis, Johann. 2018. "Climate Change Adaptation as a New Global Norm in the Water Sector? Between Symbolism and Dilution." In A Critical Approach to International Water Management Trends: Policy and Practice, edited by Christian Bréthaut and Rémi Schweizer, 177-200. London: Palgrave Macmillan UK.

\title{
Climate change adaptation as a new global norm in the water sector? Between symbolism and dilution
}

\author{
Dr Johann Dupuis
}

IDHEAP, Swiss Graduate School of Public Administration, Université de Lausanne, Quartier Mouline, Lausanne CH-1015, Switzerland

\begin{abstract}
Climate change impacts on societies and ecosystems are relatively new concerns in the water sector. A steadily growing literature emphasizes the need to reform water governance in order to make it more adaptive. In this contribution, I ask whether climate change adaptation can be considered as a new norm of policymaking and what this is implying for the governance of water. Building on the literature and on empirical material gathered from case studies, this chapter emphasizes the complex and erratic nature of adaptation policy processes, which may result in outputs that highly diverge from the positive expectations held in the literature and in international fora.
\end{abstract}




\section{Introduction}

The way we deal with certain social problems at subnational scales is influenced by global trends in the values and prescriptions that shape collective responses (Bernstein and Cashore 2012). Such constructs can be referred to as common global norms, which we define as: “intersubjective understandings that constitute actors' interests and identities, and create expectations as well as prescribe what appropriate behaviour ought to be" (Björkdahl 2002).

Common global norms are sets of influential ideas that are used to frame domestic policies (Keohane and Goldstein). For instance, the call for integrated water resource management after the Rio summit of 1992 strongly influenced environmental policymaking in developed countries (Jordan, Wurzel, and Zito 2003). Old-fashioned command and control policies came under heavy criticism for being inefficient (Cole and Grossman 1999). As a result, voluntary and market-based instruments were widely introduced in environmental policy, notably in the form of tradable water rights (Dales 1968). Starting from the early 2000, integrated water resource management came to be seen as the best and unique way to achieve sustainable development in the water sector (Rahaman and Varis 2005).

However widespread and dominant they might be, norms are not cast in stone. They evolve through time and may fade, sometimes very abruptly. As some authors suggest, we may very well be witnessing a form of paradigmatic shift in environmental thinking. The concept of sustainability might be ceding ground to that of climate change adaptation (Theys 2014). More specifically in the water sector, concerns about climate change are allegedly fueling a change of policy perspective from integrated management towards adaptive management (Engle et al. 2011).

To what extent climate change adaptation (CCA) can be considered as a new global norm, and what this is implying for water governance, is a question that needs to be addressed. Climate change adaptation has indeed become one of the trendiest topics in international debates on water governance, and more generally, on environmental management. Until the early 2000's, adapting to climate change was considered a taboo (Pielke et al. 2007 \& Sarewitz, 2007). Reducing greenhouse gas emissions (GHGs) to mitigate global warming was originally defined as the priority of the United Nations Framework Convention on Climate Change (UNFCCC) of 1992. As 
and when the political failure to limit the ever-growing GHG emissions grew patent, the attention of policymakers seemingly reorients from mitigation towards adaptation to the unavoidable symptoms of climate change.

It is scientifically indisputable that climate change causes significant alterations of social-ecological systems and that forms of adaptation are necessary. Climate impacts affect the capacity of ecosystems to deliver goods and services of upmost importance for the development and livelihood of societies, for instance freshwater, arable land, or natural disaster regulation (Daily et al. 2009, Schröter et al. 2005). Adaptation is hence a matter of concern for a multitude of policy sectors such as water management, biodiversity, agriculture, spatial planning, health or economic development (Hallegatte 2009). In the water sector, climate risks are numerous, for instance: streamflow and water quality alteration, increased flood magnitude and frequency, biodiversity loss, or sea-level rise (Settele et al. 2014).

The last IPCC report defines adaptation in a relative neutral way as: "the process of adjustment to actual or expected climate and its effects." (IPCC 2014). In substance, CCA includes all to efforts to anticipate and prevent the effects of climate change, to reduce the magnitude of climate stimuli, but also to pool the risks, or even to bear some losses (Smit et al. 2001). Article 4.1 of the UNFCCC stipulates a duty to implement and report adaptation measures. To what concerns European countries, these have been supplemented by guidelines from the European commission (Commission of the European communities 2009, 2007). However, these legal requirements are very "soft" in nature (Dreyfus and Patt 2012), meaning their coercive power remains weak.

Scientists working on adaptation have played a central role in setting adaptation on the international policy agenda (Agrawala 1998). This contributes to explain why the adaptation research community has mostly focused on the societal, economical or political barriers to the development of adaptation responses (Eisenack et al. 2014), rather than contributing to comprehensively analyze decision-making processes in relation to adaptation, or to evaluate their impacts (Biesbroek et al. 2015). If the literature generally advances the idea that climate vulnerable sectors must take stock of climate impacts in decision-making (Smit and Wandel 2006), only a few authors have discussed critically what this really implies for water governance (Becker, Huitema, and Aerts 2015, Huitema et al. 2009). 
In this chapter, I will address three key dimensions in relation to the potential impacts of climate adaptation for water governance. If adaptation has become a global common norm, then we should be witnessing a process of institutionalization within States (Bernstein and Cashore 2012), which I will first discuss. Second, norms are always based on a normative justification, namely a discourse on the moral and societal imperatives implying the appropriate actions (Björkdahl 2002). I will, therefore, try to elaborate on the normative content of adaptation. Third, a norm should provide with clear substantive prescriptions on the adequate behaviors to adopt (March and Olsen 1998). I will try to decipher, what the substantive implications of adaptation ought to be with regards to the water sector. And finally, I will conclude this chapter reflecting on how this discussion draws the shapes of a future research agenda on adaptive water governance.

\section{Adaptation institutionalization in water governance: integration \& interplay management}

In order to be effective, soft norms stemming from the international level must find ways to influence collective behaviour at the domestic level. Beyond cultural channels of diffusion such as the standardized language used to depict collective problems and how to solve them (Johnston 2001), one of the most direct norms diffusion pathways is the direct legal translation in national constituencies (Bernstein and Cashore 2012). Another channel is their integration in less formal institutions such as private laws, social contracts or collective norms of behaviour (Adger et al. 2013 Murphy, \& Sweeney, 2013).

Empirical studies have described how adaptation is being institutionalized in developed countries (Biesbroek et al. 2010, EEA 2014). The rise in importance of adaptation in policy discourses can hardly be disputed (Schipper 2006). Most States have incorporated adaptation in their policy framework, but in current practices, adaption is seldom developed as a stand-alone policy sector. A "mainstreaming" approach is said to predominate, which refers to an incremental process where adaptation is incorporated as a new layer in the existing institutional structure rather than through dedicated administrations and policies (Lesnikowski et al. 2015 BerrangFord, \& Heymann, 2015). If autonomous adaptation by private actors has been 
observed (Tompkins et al. 2010), little evidence exists that climate impacts are yet systematically integrated in private decision-making.

Adaptation mainstreaming as a process of institutional integration leads to complex settings of rules that some scholars refer to as "regimes" (Gerber et al. 2009 \& Varone, 2009, Jochim and May 2010). In these contexts, the challenge becomes to integrate and bring adaptation objectives in coherence with the existing set of rules and norms that already tend to mutually conflict. Such endeavour requires to manage the vertical interplay between various layers of institutional structures with heterogeneous attributes, and to deal with the horizontal interplay between regulations and norms with conflicting goals or effects (Vatn and Vedeld 2012, Young 2002).

Institutional coordination has precisely been identified by the literature as one of the main factors that hamper adaptation development (Krysanova et al. 2010 VarelaOrtega, \& Schlüter, 2010). According to existing assessments, even recent pieces of legislation such as the European Water Framework Directive (WFD) of 2000 poorly integrate climate impacts into risk assessments and decision-making, although goalattainment by the WFD is clearly climate-sensitive (Brouwer, Rayner, and Huitema 2013 2013, Wilby et al. 2006 Forrow, \& Blackmore, 2006).

Against similar backdrops, several authors proposed frameworks around the concept of "environmental policy integration", originally in order to assess the progress of States in incorporating sustainability into their development policies (Knoepfel 1995, Lafferty and Hovden 2003). Many scholars working on environmental policy integration in the aftermath of the Rio conference simply assumed a normative tone regarding the need to give priority to sustainability in the management of policy interplay. These authors suggested that environmental concerns should be integrated vertically, in all layers of governance and at all stages of policymaking; and horizontally, through the coordination of environmental and non-environmental policy, as to "minimise contradictions between environmental and sectoral policies by giving principled priority to the former over the latter"; (Lafferty and Hovden 2003, 9).

By analogy, the same principle could apply to adaptation; in order to be effective, adaptation goals should be coherently articulated with and given priority over potentially rival policies and rules. The adaptation literature hence emphasizes the 
need to better integrate adaptation in institutional frameworks, notably in the governance of water, and to make existing policies more supportive of adaptation (Urwin and Jordan 2008). However, under the current circumstances, it is relatively unclear how coherence is to be reached and to what extent adaptation should be prioritized over other policy objectives.

Indeed, institutionalizing adaptation may produce erratic results. In the current context of soft obligations, high uncertainty with regards to climate impacts, and low public pressure on the climate issue, the institutional integration of adaptation is prone to symbolic policymaking (Gustafsson 1983), that is actions intended to demonstrate government activity on a given problem, but with no hope of contributing to its resolution. Adaptation often gives rise to a process of policy recycling or relabeling, by which already existing measures are given a second political life under the etiquette of "adaptation”. Dupuis (2015), for instance, demonstrates how the huge integrated watershed management program (NWDPRA) launched by the Indian government in 1991 was first framed as sustainable development policy, before being newly presented as an adaptation measure in 2008.

Worse, when insufficiently coordinated with social welfare or environmental protection policies, institutionalizing adaptation in the water sector can lead to outcomes that are highly questionable in terms of legitimacy. The dam project of Sivens in the Tarn region of France is a sadly famous example of that. The project, financed by the water ministry, the EU and the Tarn department, was supposed to balance the effect of climate change on water availability to the benefit of farmers downstream of the Tescou river. The most important wetland of the region was to be flooded, however, even though it contained a rich biodiversity of about 94 protected species $^{1}$. The launch of the deforestation work triggered uproar and protests, which peaked with the death of a 21 years old demonstrator. Two days later, an assessment commissioned by the National ministry of ecology strongly criticized the project (Conseil général de l'environnement et du développement durable 2014). The project was finally abandoned 2 months later, leaving the wetland ecologically damaged. The case of Sivens is certainly extreme, but must be considered as a cautionary tale about the fact that the lack of institutional coordination between adaptation and environmental conservation leads to unpredictable effects on the ground. Had the

\footnotetext{
${ }^{1}$ http://www.collectif-testet.org/31+la-zone-humide-du-testet.html
} 
planning procedures integrated biodiversity and local people aspiration ahead in the process, alternative adaptation options with less dramatic consequences might have been advanced.

The case of Sivens strongly reminds that adaptation is being institutionalized, but without a clear blueprint on how to articulate and prioritize with existing policies (Jordan and Lenschow 2010), which can lead to erratic results in case of deficient coordination.

\section{The normative content of adaptation: the attractiveness of polysemy}

Common global norms necessarily entail a form of teleology, that is a moral justification of the societal purpose or problems they where designed to address in the first place (Habermas 1998).

At the ontological level, Eakins and al. (2009) consider that adaptation goals can be viewed through at least three different theoretical lenses: the risk-hazard literature (McCarthy et al. 2001 Dokken, \& White, 2001), political economy (Adger and Kelly 1999), and socio-ecological system theory (Gunderson and Holling 2002).

These theoretical frames imply different priorities for adaptation goals in water governance. The risk-hazard approach focus primarily on physical exposure to climate impacts and involve straightforward risk reduction responses such as building dikes or giving more room to rivers (Füssel 2007). Political economy tends to adopt a more holistic approach, in which climate change impacts are just a factor that aggravates the deeply rooted social-economical vulnerabilities of people at risk (O'Brien, Sygna, and Haugen 2004). In this approach, reducing structural social inequities through empowerment and capacity building represents the cornerstone of adaptation policy. Finally, socio-ecological system theory rather puts the emphasize on water management systems that are flexible enough to absorb external shocks while retaining the same function and structure (Nelson, Adger, and Brown 2007 2007). The point is here to build institutions that allow for adaptive management. Studies that systematically analyze and compare how these theoretical lenses diffuse into real world politics, and how they impact water management are still scarce (Dupuis and Knoepfel 2013, Eakin et al. 2009). More work is needed to identify which policy goals seem best to best work in what context as well as trade-offs and synergies. 
Interestingly, adaptation seems to have generated an image far less accurate of the societal goals to be reached than the one to be avoided. The term "maladaptation" is used to designate these negative features. A plurality of interpretation certainly exist, (Magnan et al. 2016), but maladaptation designates primarily policy objectives that program large increases of GHG emissions (Hasson, Löfgrenb, and Visser 2010), contradict sustainability principles (Brown 2011, Eriksen et al. 2011), or lock in irreversible pathways (Hallegatte 2009). Other than the Sivens case, Barnett and al. (2010) demonstrate that the water policies designed by the municipality of Melbourne to deal with climate impacts such as declining rainfalls and water availability through means of desalinization and water transport largely increase GHG emissions, and disproportionately burden most vulnerable actors. By contrast, other studies show how adaptation programs that develop irrigation potential to fight against droughts and erratic rainfalls can positively affect the social welfare of vulnerable actors, but also contribute to groundwater depletion, thereby reinforcing the adverse impacts of climate change (Dupuis and Knoepfel 2013).

Hallegatte (2009) convincingly demonstrates that positive obligations can be derived from the concept of maladaptation. He suggests that decision in the water sector should be robust to climate uncertainty by planning soft options that are reversible. He calls for a strengthening of the precautionary principle, by using safety margins for defining stricter-than-necessary targets in order to account for the additional risks of climate change. All these policy advice revolves around the concept of low-regret or no-regret strategies, namely policy options that would yield benefits even in the absence of climate change (Wilby and Dessai 2010).

Robust adaptation may seem the most policy-relevant way to frame adaptation goals. At the same time however, it carries a conservative tone and dilutes the specificities of adaptation. The precautionary approach emphasized to deal with the uncertainty carries the risk of excluding innovative and progressive measures designed to specifically address future climate change impacts. Robust adaptation therefore leads to a focus on the most proximate causes of climate vulnerability, and omits the systemic changes that might be needed in order to cope with future climate impacts of larger magnitude (Wise et al. 2014).

It is also questionable whether robust adaptation adds any value to current water policies. The inclusion of safety margins in the design of flood prevention systems, 
for instance, is not new per se. Similar advice was made to strengthen flood risk policies well before climate change became a policy issue (Burton, Kates, and White 1978). These redundancies have raised the skepticism among scholars within the disaster risk reduction community about the novelty and added-value of adaptation (Mercer 2010).

In reaction to the incrementalism and precautionary approach underlying robust adaptation, the recent literature, and notably the last IPCC report, emphasizes the need for transformational adaptation (Kates, Travis, and Wilbanks 2012, Klein et al. 2014, Preston, Dow, and Berkhout 2013). Transformational adaptation can be understood as the opposite image of robust adaptation. In answer to the risks of climate impacts of unpredictable magnitude, transformational adaptation are interventions of a paradigmatic nature that ambition to transfigure the existing practices in water management. At the same time, transformation is more likely to encounter resistance and typically represent less feasible options to decision-makers (Dupuis and Knoepfel 2013). Moreover, promoting transformation is more at risk of ending up in maladaptive options, if the climate and other contextual conditions evolve differently than anticipated.

Robustness and transformation form a continuum of targeted societal change in relation to adaptation. While trade-offs are inevitable between the two approaches, some scholars argument that they are not mutually exclusive and might in fact be complementary (Wise et al. 2014). Robust adaptation can constitute a first response to most proximate vulnerabilities while incrementally supporting transformation. How such pathway of change can occurred in current water governance structures is an open question, since identifying the social-political mechanisms that may conduct to these pathways of change needs further research (Gillard et al. 2016 \& Van Alstine, 2016).

Adaptation hence hardly comes with univocal expectations about the societal goals to be reached. This might come as a reason not to consider adaptation as a norm, since norms are precisely defined as normative "standard" that leaves a narrow margin of interpretation (Axelrod 1986). But one should also recall that contested notions such as sustainability can act as global norms, as long as they produce ethics and identities that can be appropriated (Lafferty 1996). Even more so in the case of sustainability, normative indistinctness allowed for social forces pursuing antagonist interests such 
as NGOs or business organizations to commonly support sustainability, as an objective they could interpret according to their stakes. The uncertainty resulting from unclear norms in turn allows a process of translation or "transcoding" (Lascoumes 1996) through which actors strive to clarify the norm according to their own interests and beliefs, in order to strengthen their position in existing policy networks.

Turning back to adaptation, scholars make the empirical observation that adaptation initiatives are discussed almost everywhere, but the values shaping adaptation goals differ contextually (Adger et al. 2009). The norm broadness here clearly results in a process of norm translation, whereby States and private actors have an important leeway in interpreting the meaning of adaptation according to their own values and interests. For instance, the Government of India views adaptation as something that would be reached through social welfare development, whereas, Switzerland defines it as a way to seize the new economic opportunities offered by climate change (Dupuis 2015). In a certain sense, adaptation can be considered as a contested norm that suffers from polysemy. Goals unclarity is paradoxically turning adaptation into a globally attractive policy idea, since it allows government or other policy actors to recycle "old wine in new bottles", and to use adaptation to fuel their own political project.

\section{The substantive content of adaptation. The gospel of flexibility and the omission of policy and politics}

Norms also carry expectations and prescriptions about the appropriate behaviour to adopt, the ought and the ought not, in relation to a given issue. At the policy level, norms act as a reference that bounds the choice of desirable rules, instruments and procedures by decision-makers (Hall 1993).

In relation to climate change adaptation, a powerful discourse has emerged in scientific as well as in policy circles about the conditions enabling "the good governance" of natural resources. Inspired by the work of Nobel prize Elinor Ostrom (2005), and by the literature on adaptive management (Olsson, Folke, and Berkes 2004), these ideas have exerted a strong influence in water policy debates and practices, where they often go by the name of "adaptive water governance".

Adaptive governance can be traced back to the work of Holling (1973), who strongly criticized centralized governance systems, fixed top-down procedures and 
environmental protection policies for unfitting the complex and non-linear attributes of change dynamics in ecosystems. Formal policies that aim to increase the predictability of actors' behaviour by formulating wrongs and rights were viewed as too rigid and myopic to manage always evolving ecosystems. Holling argued hat "bureaucracies are an exercise in variance reduction through regulation and control", which ultimately contributes to creating bigger environmental problems than the ones they were supposed to solve in the first place (Holling and Meffe 1996, 331). Decision-making structures deployed in water and natural resources governance were also considered as too centralized and hierarchical to leave room for deliberation with local stakeholders, what prevents the types of innovative, creative and reactive management needed in order to adapt to environmental changes (Holling and Gunderson 2002, Holling and Meffe 1996).

A growing literature sought to use cross-case comparisons and meta-case analysis to demonstrate empirical regularities between the features of adaptive governance and successful adaptation in the water sector, as well as the lack of adaptive capacity of centralized and command and control types of water governance systems (Huntjens et al. 2012, Huntjens et al. 2011, Pahl-Wostl 2007, Pahl-Wostl and Knieper 2014, PahlWostl et al. 2012 \& Nikitina, 2012).

While this literature prudently recalls that no panacea exists, it strongly asserts that successful adaptation is both theoretically and empirically related to the existence of flexible institutions that are able to deal with complexity and uncertainty. It is claimed this requires new institutional arrangement in many cases. Such institutions would combine three features: polycentrism (multilevel and nested structure with many centres of decision-making that are formally independent, but interconnected and partially redundant); adaptive management system; and strong stakeholders participation (Huitema et al. 2009). ${ }^{2}$

It is claimed that flexibilizing policies allow for experimenting innovative policy solutions and constantly evolving practices based on permanent monitoring and knowledge management. Decision-making should occur at the lowest level of governance in close collaboration with the higher-levels on cross-scale issues, as to

\footnotetext{
${ }^{2}$ According to Huitema (2009), "bioregionalization", namely the geographical rescaling of governance institutions to ecosystem frontiers, constitutes another dimension of these prescriptions. I will not deal with this subject here, as the chapter from Arnaud Buchs probably discusses that extensively.
} 
allow both social learning across levels, as well as leadership at the individual level (Armitage et al. 2008, Lebel et al. 2006). Moreover, these polycentric decision networks should facilitate stakeholder participation and the use of local knowledge to inform governance choices. All in all, adaptive management in polycentric governance settings would facilitate trust-building among water stakeholders, and enable the emergence of innovation in response to climate change impacts.

Adaptive water governance has become the dominant discourse in policy debates on climate and water (Reghezza-Zitt et al. 2012). Few scholars have attempted to challenge what seems to have become a doxa about the way to bring water governance to a climate adaptive state (Huitema et al. 2009, Plummer et al. 2012).

However, both the conceptual and methodological foundations of the prescriptions around adaptive governance remain fragile. Indeed, the implementation of adaptation initiatives in the water sector is yet too recent to allow for solid comparative analysis and outcomes evaluation (Dupuis and Biesbroek 2013). The empirical studies that posit the superiority of adaptive governance use indicators of adaptive capacity such as the existence of explicit adaptation strategies or adaptation measures, which unfortunately says very little about the effectiveness of these policy outputs to deal with climate impacts (Huntjens et al. 2012).

Another problem relates to the fact that concepts such as polycentrism are complex theoretical construct that are difficult to apply to the social reality through easily measurable proxies. Existing studies tend to build exaggeratedly clear dichotomies between polycentric and centralized system that do not hold in reality. Centralization only opposes to decentralization and both systems can be more or less polycentric (Pahl-Wostl and Knieper 2014). The normative tone surrounding the debates on polycentrism also eludes discussion on the drawback of this model for water governance. Polycentrism can well imply higher transaction costs, less accountability, and more coordination conflicts than a hierarchical governance with clearly divided competence and responsibilities (Huitema et al. 2009).

Advocacy in favour of adaptive management generally omits to discuss the qualities of traditional environmental policy. The formalization of environmental obligations in laws and policies impede rapid adaptation, precisely because they seek to make fundamental norms such as equal access to natural resources or just redistribution 
resistant to political changes (Ruhl 2012). Moreover, in many cases, flexibility has already become an intrinsic feature of water policy. For instance, the WFD, which is nothing less than a top-down policy, stipulates the introduction of water-pricing instruments and broad stakeholders participation (Aubin and Varone 2004). In that sense, neither formalization nor top-down policy precludes flexible management at the lower levels of decision-making (Ebbesson 2010).

Implementing adaptive management systems can be considered as the principal substantive prescription in relation to adaptation. However, it is important to note that adaptive governance addresses mainly the structure of governing institutions (the polity), whereas it has only little to say about policy instruments, nor does it seem to consider politics and power. For example, when the WFD began to be implemented in European States, one of the main worries of political scientists concerned the lack of policy instruments for influencing water quality in cases where water disturbances originate from private owners of adjacent land (Aubin and Varone 2004). In this situation, adaptive governance is ill-equipped to advise which of water pricing, payment for environmental services or land exchange would be to most "adaptive" or effective policy instruments to solve the environmental problem.

Moreover, the idea of adaptive governance entails a very naïve vision of power relations in collective action. A very optimistic view dominates that natural resource stakeholders are rational thinkers willing to adopt innovative behaviour and strategies to sustain ecosystems, if institutions are correctly designed (Olsson, Folke, and Hahn 2004). Such perspective omits agency. Collective decision-making is a process formed by actors' interactions that is at least as chaotic and unpredictable as climate change. Moreover, social learning is unlikely in polycentric networks of decisions that involve highly heterogeneous actors in terms of interest, and a strong degree of power fragmentation. One just need to think about the difficulty of finding agreement on optimal environmental protection levels between small scale resource users and multinational firms, which always have the possibility to opt out (Dupuis and Knoepfel 2015, Lima et al. 2006). In such settings, the exercise of hierarchy by public authority with democratic legitimacy might represent the only option to reach a decision outcome (Knoepfel and Kissling-Naf 1998, Papadopoulos and Warin 2007). Finally, in complex social-political systems, implementing adaptive governance in the water sector will not necessarily benefit all actors, but implies winners and losers. In 
Switzerland, the $3^{\text {rd }}$ Rhone correction is a very ambitious project that aims to increase the capacity to deal with floods of a return period ranging from 100 to 1000 years. The project incorporates features of adaptive governance, notably an emphasis on social learning and flexible decision-making (Arborino 2011). Farmers of the region strongly opposed the project and felt being prejudiced by it. Indeed, the proposed solution to increasing the resilience to flood risks involved using arable land as submersible zones. Yet the buildings that surrounding municipalities allowed constructing too near from the riverbed will be maintained, although it constitutes the main cause of present and future vulnerability.

As outcomes of water governance reforms always depend to some extent on past choices and on the balance of power between local stakeholders, it appears doubtful that adaptive governance will universally be perceived as a progress. Enhancing the capacity to deal with environmental changes in the water sector is certainly a good thing that adaptive governance might be able to do; but simultaneously contributing to economic development and social equity in resource access is another, which might stay out of hands. Here the case of the $3^{\text {rd }}$ Rhone correction demonstrates, but one thing : that an analysis in terms of actors and politics cannot be omitted if the impacts of adaptation are to be understood.

\section{Conclusive discussion}

In this chapter, I discussed whether climate change adaptation can be considered as a new global norm, and what this is implying for the water sector. I have focused on three dimensions of norms, investigating whether adaptation is being institutionalized in water governance; what normative content is being conveyed; and whether clear substantive prescriptions on the collective behaviour to adopt exist. I have reviewed the evidences, drawing from the literature and existing case studies to make the following observations.

First, adaptation acts as a global norm with respects to the fact that signs of institutionalization can be distinguished worldwide. However, this process is plagued by symbolism and coordination problems, which contributes to producing erratic results.

Second, adaptation has not yet crystallized into a common understanding of the societal goals to be reached, but several conceptions coexist. If this indicates that the 
normative foundation of adaptation still lack solidity, the solubility and broadness of the concept actually participate to its attractiveness for policymakers. The diluted meaning of adaptation may very well be exploited in politics, as a way for actors to legitimate old policy solutions or to consolidate their position in policy networks.

Third, adaptation conveys strong prescriptions on the need to make water governance more flexible, polycentric and participative. Confronted to power and politics in concrete decision-making, these advices tend to lose their substance, however.

In a nutshell, adaptation to climate change can be considered as a global norm that has penetrated water governance, but symbolic policymaking, goals unclarity and abstract prescriptions contribute to creating erratic outcomes. This situation draws a clear research agenda: there is a need to analyse comprehensively adaptation processes in the water sector; to develop an in-depth understanding of the pathways of change towards adaptive governance; and to advance implementation studies that seek to identify common patterns in policy outcomes. Because adaptation has long been the poor relation in climate research, it is quite understandable that existing studies focused on providing theoretical guidance on adaptation, and on identifying barriers and deficits. It is however time to switch from a normative and descriptive agenda towards an analytical and explicative one.

\section{Acknowledgments:}

This research has been financed through the Swiss National Science Foundation, grant: 100017_153525. 


\section{Bibliography}

Adger, W.N., S Dessai, M Goulden, M Hulme, I Lorenzoni, D.R Nelson, L.O Naess, J Wolf, and A Wreford. 2009. "Are there social limits to adaptation to climate change?" Climatic Change 93 (3):335-354.

Adger, W.N., and P. Mick Kelly. 1999. "Social Vulnerability to Climate Change and the Architecture of Entitlements." Mitigation and Adaptation Strategies for Global Change 4 (3):253-266.

Adger, W.N., Tara Quinn, Irene Lorenzoni, Conor Murphy, and John Sweeney. 2013. "Changing social contracts in climate-change adaptation." Nature Clim. Change 3 (4):330-333.

Agrawala, S. 1998. "Context and early origins of the Intergovernmental Panel on Climate Change." Climatic Change 39 (4):605-620.

Arborino, T. 2011. "Prise en compte du changement climatique dans la gestion du risque inondation : l'exemple du Rhône en Valais." Séminaire international d'experts «Adaptation de la gestion des risques naturels face au changement climatique », Domancy, France.

Armitage, Derek R., Ryan Plummer, Fikret Berkes, Robert I. Arthur, Anthony T. Charles, Iain J. Davidson-Hunt, Alan P. Diduck, Nancy C. Doubleday, Derek S. Johnson, Melissa Marschke, Patrick McConney, Evelyn W. Pinkerton, and Eva K. Wollenberg. 2008. "Adaptive co-management for social-ecological complexity." Frontiers in Ecology and the Environment 7 (2):95-102. doi: 10.1890/070089.

Aubin, David, and Frédéric Varone. 2004. "The Evolution of European Water Policy." In The Evolution of National Water Regimes in Europe: Transitions in Water Rights and Water Policies, edited by Ingrid Kissling-Näf and Stefan Kuks, 49-86. Dordrecht: Springer Netherlands.

Axelrod, Robert. 1986. "An evolutionary approach to norms." American political science review 80 (04): 1095-1111.

Barnett, Jon, and Saffron O'Neill. 2010. "Maladaptation." Global Environmental Change 20 (2):211-213. doi: 10.1016/j.gloenvcha.2009.11.004.

Becker, Gert, Dave Huitema, and Jeroen CJH Aerts. 2015. "Prescriptions for adaptive comanagement: the case of flood management in the German Rhine basin." Ecology and Society 20 (3):1.

Bernstein, Steven, and Benjamin Cashore. 2012. "Complex global governance and domestic policies: four pathways of influence." International Affairs 88 (3):585-604.

Biesbroek, G.R., J. Dupuis, Andrew Jordan, Adam Wellstead, Michael Howlett, Paul Cairney, Jeremy Rayner, and Debra Davidson. 2015. "Opening up the black box of adaptation decision-making." Nature Clim. Change 5 (6):493-494. doi: 10.1038/nclimate2615.

Biesbroek, Robbert, R.J Swart, T.R Carter, C Cowan, T Henrichs, H Mela, M.D Morecroft, and D Rey. 2010. "Europe adapts to climate change: comparing national adaptation strategies." Global Environmental Change 20 (3):440450 . 
Björkdahl, Annika. 2002. "Norms in International Relations: Some Conceptual and Methodological Reflections." Cambridge Review of International Affairs 15 (1):9-23. doi: 10.1080/09557570220126216.

Brouwer, Stijn, Tim Rayner, and Dave Huitema. 2013. "Mainstreaming climate policy. The case of climate adaptation and the implementation of EU water policy." Environment and Planning C 31 (1):134-153.

Brown, Katrina. 2011. "Sustainable adaptation: An oxymoron?" Climate and Development 3 (1):21-31.

Burton, I., R. Kates, and G. White. 1978. The Environment as Hazard. New York: Oxford University Press.

Cole, D , and Z. Grossman. 1999. "When is command and control efficient Institutions, technology, and the comparative efficiency of alternative regulatory regime for environmental protection." Wisconsin Law Review 887:887-938.

Commission of the European communities. 2007. Green paper from the commission to the council, the european parliament, the european economic and social committee and the committee of the regions. Adapting to climate change in Europe - options for EU action. edited by Commission of the European communities.

Commission of the European communities. 2009. White Paper. Adapting to climate change: Towards a European framework for action. edited by Commission of the European communities.

Conseil général de l'environnement et du développement durable. 2014. Expertise $d u$ projet de barrage de Sivens. Paris: Ministère de l'Écologie du Développement durable et de l'Énergie,.

Daily, Gretchen C., Stephen Polasky, Joshua Goldstein, Peter M. Kareiva, Harold A. Mooney, Liba Pejchar, Taylor H. Ricketts, James Salzman, and Robert Shallenberger. 2009. "Ecosystem services in decision making: time to deliver." Frontiers in Ecology and the Environment 7 (1):21-28. doi: 10.1890/080025.

Dales, J.H. 1968. Pollution propery and prices : an essay in policy-making and economics. Toronto: University Of Toronto Press.

Dreyfus, Magali, and Anthony Patt. 2012. "The European Commission White Paper on adaptation: appraising its strategic success as an instrument of soft law." Mitigation and Adaptation Strategies for Global Change 17 (8):849-863. doi: 10.1007/s11027-011-9348-0.

Dupuis, J. 2015. S'adapter au changement climatique : analyse critique des nouvelles politiques de gestion de l'environnement. Cas spécifiques de l'agriculture en Inde et du tourisme hivernal en Suisse. Neuchâtel: Éditions Alphil-Presses universitaires suisses.

Dupuis, J., and Robbert Biesbroek. 2013. "Comparing apples and oranges: The dependent variable problem in comparing and evaluating climate change adaptation policies." Global Environmental Change 23 (6):1476-1487. doi: 10.1016/j.gloenvcha.2013.07.022.

Dupuis, J., and P. Knoepfel. 2013. "The Adaptation Policy Paradox: the Implementation Deficit of Policies Framed as Climate Change Adaptation." Ecology and Society 18 (4). doi: 10.5751/es-05965-180431.

Dupuis, J., and P. Knoepfel. 2015. The Politics of Contaminated Sites Management. Edited by Springer. Dordrecht, Heidelberg, London, New York: Springer international. 
Eakin, H., E.L. Tompkins, D.R. Nelson, and J.M. Anderies. 2009. "Hidden costs and disparate uncertainties: trade-offs involved in approaches to climate policy." In Adapting to Climate Change: Thresholds, Values, Governance, edited by W.N. Adger, I Lorenzoni and K. O'Brien. New-York: Cambridge University Press.

Ebbesson, Jonas. 2010. "The rule of law in governance of complex socio-ecological changes." Global Environmental Change 20 (3):414-422.

EEA. 2014. National adaptation policy processes in European countries - 2014. Luxembourg: EEA.

Eisenack, Klaus, Susanne C. Moser, Esther Hoffmann, Richard J. T. Klein, Christoph Oberlack, Anna Pechan, Maja Rotter, and Catrien J. A. M. Termeer. 2014. "Explaining and overcoming barriers to climate change adaptation." Nature Clim. Change 4 (10):867-872. doi: 10.1038/nclimate2350.

Engle, Nathan L, Owen R Johns, Maria Carmen Lemos, and Donald R Nelson. 2011. "Integrated and adaptive management of water resources: tensions, legacies, and the next best thing." Ecology and society 16 (1):19.

Eriksen, S.H., Paulina Aldunce, Chandra Sekhar Bahinipati, Rafael D'Almeida Martins, John Isaac Molefe, Charles Nhemachena, K. O'Brien, Felix Olorunfemi, Jacob Park, Linda Sygna, and Kirsten Ulsrud. 2011. "When not every response to climate change is a good one: Identifying principles for sustainable adaptation." Climate and Development 3 (1):7-20. doi: 10.3763/cdev.2010.0060.

Füssel, H.M. 2007. "Vulnerability: A generally applicable conceptual framework for climate change research." Global Environmental Change 17 (2):155-167.

Gerber, J-D., P. Knoepfel, S. Nahrath, and Frédéric Varone. 2009. "Institutional Resource Regimes: Towards sustainability through the combination of property-rights theory and policy analysis." Ecological Economics 68 (3):798-809.

Gillard, Ross, Andrew Gouldson, Jouni Paavola, and James Van Alstine. 2016. "Transformational responses to climate change: beyond a systems perspective of social change in mitigation and adaptation." Wiley Interdisciplinary Reviews: Climate Change.

Gunderson, Lance, and C.S. Holling, eds. 2002. Panarchy: Understanding transformations in human and natural systems. Washington, Covelo, London: Island Press.

Gustafsson, Gunnel. 1983. "Symbolic and pseudo policies as responses to diffusion of power." Policy sciences 15 (3):269-287.

Habermas, Jürgen. 1998. Between facts and norms: Contributions to a discourse theory of law and democracy. Cambridge, London: The MIT Press.

Hall, P.A. 1993. "Policy Paradigms, Social Learning, and the State: The Case of Economic Policymaking in Britain." Comparative Politics 25 (3):275-296.

Hallegatte, Stéphane. 2009. "Strategies to adapt to an uncertain climate change." Global Environmental Change 19 (2):240-247.

Hasson, Reviva, Åsa Löfgrenb, and Martine Visser. 2010. "Climate change in a public goods game: investment decision in mitigation versus adaptation." Ecological Economics 70 (2):331-338.

Holling, C.S. 1973. "Resilience and stability of ecological systems." Annual Review of Ecology and Systematics 4:1-23.

Holling, C.S., and Lance Gunderson. 2002. "Resilience and adaptive cycles." In Panarchy: Understanding transformations in human and natural systems, 
edited by Lance H. Gunderson and C. S. Holling. Washington, Covelo, London: Island Press.

Holling, C.S., and Gary K Meffe. 1996. "Command and control and the pathology of natural resource management." Conservation biology 10 (2):328-337.

Huitema, Dave, Erik Mostert, Wouter Egas, Sabine Moellenkamp, Claudia PahlWostl, and Resul Yalcin. 2009. "Adaptive water governance: assessing the institutional prescriptions of adaptive (co-) management from a governance perspective and defining a research agenda." Ecology and Society 14 (1):26.

Huntjens, Patrick, Louis Lebel, Claudia Pahl-Wostl, Jeff Camkin, Roland Schulze, and Nicole Kranz. 2012. "Institutional design propositions for the governance of adaptation to climate change in the water sector." Global Environmental Change 22 (1):67-81. doi: 10.1016/j.gloenvcha.2011.09.015.

Huntjens, Patrick, Claudia Pahl-Wostl, Benoit Rihoux, Maja Schlüter, Zsuzsanna Flachner, Susana Neto, Romana Koskova, Chris Dickens, and Isah Nabide Kiti. 2011. "Adaptive Water Management and Policy Learning in a Changing Climate: a Formal Comparative Analysis of Eight Water Management Regimes in Europe, Africa and Asia." Environmental Policy and Governance 21 (3):145-163. doi: 10.1002/eet.571.

IPCC. 2014. Climate Change 2014: Synthesis Report. Contribution of Working Groups I, II and III to the Fifth Assessment Report of the Intergovernmental Panel on Climate Change. edited by R.K. Pachauri and L.A. Meyer. Geneva, Switzerland: IPCC.

Jochim, Ashley E., and Peter J. May. 2010. "Beyond Subsystems: Policy Regimes and Governance." Policy Studies Journal 38 (2):303-327. doi: 10.1111/j.15410072.2010.00363.x.

Johnston, Alastair Iain. 2001. "Treating international institutions as social environments." International Studies Quarterly 45 (4):487-515.

Jordan, Andrew, and Andrea Lenschow. 2010. "Environmental policy integration: a state of the art review." Environmental Policy and Governance 20 (3):147158.

Jordan, Andrew, Rüdiger K. W. Wurzel, and Anthony R. Zito. 2003. "'New' Instruments of Environmental Governance: Patterns and Pathways of Change." Environmental Politics 12 (1):1-24. doi: 10.1080/714000665.

Kates, Robert W., William R. Travis, and Thomas J. Wilbanks. 2012. "Transformational adaptation when incremental adaptations to climate change are insufficient." Proceedings of the National Academy of Sciences 109 (19):7156-7161. doi: 10.1073/pnas.1115521109.

Keohane, Robert O., and Judith Goldstein. 1993. "Ideas and Foreign Policy: An Analytical Framework." In Ideas and Foreign Policy: Beliefs, Institutions, and Political Change, edited by Judith Goldstein, 3-30. Ithaca: Cornell University Press.

Klein, Richard J.T., Guy F. Midgley, Benjamin L. Preston, Mozaharul Alam, Frans G.H. Berkhout, Kirstin Dow, and Rebecca Shaw. 2014. "Adaptation Opportunities, Constraints, and Limits." In Climate Change 2014: Impacts, Adaptation, and Vulnerability. Part A: Global and Sectoral Aspects. Contribution of Working Group II to the Fifth Assessment Report of the Intergovernmental Panel on Climate Change edited by C.B. Field, V.R. Barros, D.J. Dokken, K.J. Mach, M.D. Mastrandrea, T.E. Bilir, M. Chatterjee, K.L. Ebi, Y.O. Estrada, R.C. Genova, B. Girma, E.S. Kissel, A.N. Levy, S. 
MacCracken, P.R. Mastrandrea and L.L. White. Cambridge, United Kingdom and New York, NY, USA: Cambridge University Press.

Knoepfel, P. 1995. "New Institutional Arrangements for the Next Generation of Environmental Policy Instruments: Intra- and Interpolicy-Co-operation." In Environmental Policy: in Search of New Instruments, edited by B. Dente, 150-170. Dordrecht: Kluwer.

Knoepfel, Peter, and Ingrid Kissling-Naf. 1998. "Social learning in policy networks." Policy \& Politics 26 (3):343-367.

Krysanova, V., C. Dickens, J. Timmerman, C. Varela-Ortega, and M. Schlüter, Roest, K. 2010. "Cross-Comparison of Climate Change Adaptation Strategies Across Large River Basins in Europe, Africa and Asia." Water Resources Management 24 (14):4121-4160.

Lafferty, William, and Eivind Hovden. 2003. "Environmental policy integration: towards an analytical framework." Environmental Politics 12 (3):1-22. doi: 10.1080/09644010412331308254.

Lafferty, William M. 1996. "The politics of sustainable development: Global norms for national implementation." Environmental Politics 5 (2):185-208. doi: 10.1080/09644019608414261.

Lascoumes, Pierre. 1996. "Rendre gouvernable : de la "traduction" au "transcodage" : l'analyse des processus de changement dans les réseaux d'action publique " In La Gouvernabilité, 325-338. Paris: Presses universitaires de France.

Lebel, L., J.M. Anderies, B. Campbell, C. Folke, S. Hatfield-Dodds, T.P. Hughes, and J. Wilson. 2006. "Governance and the capacity to manage resilience in regional social-ecological systems." Ecology and Society 11 (1):19.

Lesnikowski, Alexandra, James Ford, Robbert Biesbroek, Lea Berrang-Ford, and S Jody Heymann. 2015. "National-level progress on adaptation." Nature Climate Change.

Lima, Eirivelthon, Frank Merry, Daniel Nepstad, Gregory Amacher, Cl $\sqrt{ }{ }^{\circ}$ udia Azevedo-Ramos, Paul Lefebvre, and Felipe Resque. 2006. "Searching for sustainability: forest policies, smallholders, and the Trans-Amazon highway." Environment: Science and Policy for Sustainable Development 48 (1):26-38.

Magnan, A. K., E. L. F. Schipper, M. Burkett, S. Bharwani, I. Burton, S. Eriksen, F. Gemenne, J. Schaar, and G. Ziervogel. 2016. "Addressing the risk of maladaptation to climate change." Wiley Interdisciplinary Reviews: Climate Change:n/a-n/a. doi: $10.1002 /$ wcc.409.

March, James G., and Johan P. Olsen. 1998. "The Institutional Dynamics of International Political Orders." International Organization 52 (04):943-969.

McCarthy, J.J, O.F Canziani, N.A Leary, D.J Dokken, and K.S. White. 2001. Climate Change 2001: Impacts, Adaptation and Vulnerability. Edited by IPCC. Cambridge: Cambridge University Press.

Mercer, Jessica. 2010. "Disaster risk reduction or climate change adaptation: Are we reinventing the wheel?" Journal of International Development 22 (2):247264. doi: 10.1002/jid.1677.

Nelson, Donald R, W.N. Adger, and Katrina Brown. 2007. "Adaptation to environmental change: contributions of a resilience framework." Annual Review of Environment and Resources 32 (1):395-419.

O'Brien, K., L Sygna, and JE Haugen. 2004. "Vulnerable or resilient? A multi-scale assessment of climate impacts and vulnerability in Norway." Climatic Change 64 (1):193-225. 
Olsson, P., C. Folke, and T. Hahn. 2004. "Social-ecological transformation for ecosystem management: the development of adaptive co-management of a wetland landscape in southern Sweden." Ecology and Society 9 (4):2.

Olsson, Per, Carl Folke, and Fikret Berkes. 2004. "Adaptive Comanagement for Building Resilience in Social-Ecological Systems." Environmental Management 34 (1):75-90. doi: 10.1007/s00267-003-0101-7.

Ostrom, E. 2005. Understanding institutional diversity. Princeton, Oxfordshire: Princeton University Press.

Pahl-Wostl, Claudia. 2007. "Transitions towards adaptive management of water facing climate and global change." Water Resources Management 21 (1):4962. doi: 10.1007/s11269-006-9040-4.

Pahl-Wostl, Claudia, and Christian Knieper. 2014. "The capacity of water governance to deal with the climate change adaptation challenge: Using fuzzy set qualitative comparative analysis to distinguish between polycentric, fragmented and centralized regimes." Global Environmental Change 29:139154.

Pahl-Wostl, Claudia, Louis Lebel, Christian Knieper, and Elena Nikitina. 2012. "From applying panaceas to mastering complexity: Toward adaptive water governance in river basins." Environmental Science \& Policy 23 (0):24-34 doi: http://dx.doi.org/10.1016/j.envsci.2012.07.014.

Papadopoulos, Y., and P. Warin. 2007. "Are innovative, participatory and deliberative procedures in policy making democratic and effective?" European Journal of Political Research 46 (4):445-472.

Pielke, R.A., G. Prins, S. Rayner, and D. Sarewitz. 2007. "Lifting the taboo on adaptation." Nature 445 (8):597-598.

Plummer, Ryan, Beatrice Crona, Derek R Armitage, Per Olsson, Maria Tengö, and Olga Yudina. 2012. "Adaptive comanagement: a systematic review and analysis." Ecology and Society 17 (3):11.

Preston, Benjamin L, Kirstin Dow, and Frans Berkhout. 2013. "The Climate Adaptation Frontier." Sustainability 5 (3):1011-1035.

Rahaman, Muhammad Mizanur, and Olli Varis. 2005. "Integrated water resources management: evolution, prospects and future challenges." Sustainability: Science, Practice, \& Policy 1 (1).

Reghezza-Zitt, Magali, Samuel Rufat, Géraldine Djament-Tran, Antoine Le Blanc, and Serge Lhomme. 2012. What Resilience Is Not: Uses and Abuses. Cybergeo : European Journal of Geography Accessed 25.09.2013. doi: $10.4000 /$ cybergeo. 25554 .

Ruhl, J. B. 2012. "Panarchy and the Law." Ecology and Society 17 (3). doi: 10.5751/es-05109-170331.

Schipper, E.L.F. 2006. "Conceptual History of Adaptation in the UNFCCC Process." Review of European Community \& International Environmental Law 15 (1):82-92.

Schröter, Dagmar, Wolfgang Cramer, Rik Leemans, I Colin Prentice, Miguel B Araújo, Nigel W Arnell, Alberte Bondeau, Harald Bugmann, Timothy R Carter, Carlos A Gracia, Anne C. de la Vega-Leinert, Markus Erhard, Frank Ewert, Margaret Glendining, Joanna I. House, Susanna Kankaanpää, Richard J. T. Klein, Sandra Lavorel, Marcus Lindner, Marc J. Metzger, Jeannette Meyer, Timothy D. Mitchell, Isabelle Reginster, Mark Rounsevell, Santi Sabaté, Stephen Sitch, Ben Smith, Jo Smith, Pete Smith, Martin T. Sykes, Kirsten Thonicke, Wilfried Thuiller, Gill Tuck, Sönke Zaehle, and Bärbel 
Zierl. 2005. "Ecosystem service supply and vulnerability to global change in Europe." Science 310 (5752):1333-1337.

Settele, J., R. Scholes, R. Betts, S. E. Bunn, P. Leadley, D. Nepstad, J. T. Overpeck, and M. A. Taboada. 2014. "Terrestrial and inland water systems." Climate Change 2014: Impacts, Adaptation, and Vulnerability. Part A: Global and Sectoral Aspects. Contribution of Working Group II to the Fifth Assessment Report of the Intergovernmental Panel of Climate Change:271-359.

Smit, B., O Pilifosova, I. Burton, Richard J.T. Klein, B. Challenger, S. Huq, and G. Yohe. 2001. "Adaptation to climate change in the context of sustainable development and equity." In Climate change 2001: Impacts, Adaptation, Vulnerability. Contribution of Working Group II to the Third Assessment Report of the Intergovernmental Panel on Climate Change, edited by J.J McCarthy, O.F Canziani, N.A Leary, D.J Dokken and K.S White. Cambridge: Cambridge University Press.

Smit, B., and J. Wandel. 2006. "Adaptation, adaptive capacity and vulnerability." Global Environmental Change 16 (3):282-292.

Theys, J. 2014. Le développement durable face à sa crise : un concept menacé, sousexploité ou dépassé ? . Développement durable et territoires 5 (1). Accessed 10 April 2014. doi:10.4000/developpementdurable.10196

Tompkins, E.L., W.N. Adger, E. Boyd, S. Nicholson-Cole, K. Weatherhead, and N. Arnell. 2010. "Observed adaptation to climate change: UK evidence of transition to a well-adapting society." Global Environmental Change 20 (4):627-635.

Urwin, K., and A. Jordan. 2008. "Does public policy support or undermine climate change adaptation? Exploring policy interplay across different scales of governance." Global Environmental Change 18 (1):180-191.

Vatn, Arild, and Paul Vedeld. 2012. "Fit, interplay, and scale: a diagnosis." Ecology and Society 17 (4):12.

Wilby, R. L., and Suraje Dessai. 2010. "Robust adaptation to climate change." Weather 65 (7):180-185. doi: 10.1002/wea.543.

Wilby, R. L., H. G. Orr, M. Hedger, D. Forrow, and M. Blackmore. 2006. "Risks posed by climate change to the delivery of Water Framework Directive objectives in the UK." Environment International 32 (8):1043-1055. doi: http://dx.doi.org/10.1016/j.envint.2006.06.017.

Wise, R. M., I. Fazey, M. Stafford Smith, S. E. Park, H. C. Eakin, E. R. M. Archer Van Garderen, and B. Campbell. 2014. "Reconceptualising adaptation to climate change as part of pathways of change and response." Global Environmental Change 28:325-336. doi: http://dx.doi.org/10.1016/j.gloenvcha.2013.12.002.

Young, O.R. 2002. The institutional dimensions of environmental change: fit, interplay, and scale. Cambridge, London: The MIT press. 